\title{
Tensions and Relations on the Use and Exchange of Place
}

\author{
JosAnn Cutajar ${ }^{1}$
}

A community's knowledge and understanding of a place is rarely taken into consideration when urban projects are envisaged for 'blighted areas'. When residents are not consulted, the project can have negative repercussions on the community in question. This paper explores why residents and service providers had to resort to action to ensure that community regeneration is returned "to its proper function: as providing people with decent cities to live, work and leisure in" (Blackshaw, 2012, p. 185). A participant action research approach was adopted to promote the needs and interests of the community. The objective of this action was to provide decent and affordable housing for residents earning an average wage or less, while safeguarding the tangible heritage in this socially deprived area. Heritage is a source of empowerment for people living in this area. [Article copies available for a fee from The Transformative Studies Institute. E-mail address: journal@transformativestudies.org Website: http://www.transformativestudies.org (c2020 by The Transformative Studies Institute. All rights reserved.]

KEYWORDS: Place Narratives, Regeneration of Socially Deprived Areas, Decent Housing, Tangible Heritage, Agency.

\section{INTRODUCTION}

This paper is about a contentious social housing project taking place in the Hanover area in Bormla (also known as Cospicua), a city which in Malta is regarded as a socially deprived area. This housing project was first mentioned in 1998 but a number of things occurred over time to

\footnotetext{
${ }^{1}$ JosAnn Cutajar, Ph.D., is a senior lecturer and sociologist that has always been interested in community development and social justice. These issues were the focus of her teaching and research. Eventually she became the director of the University of Malta Cottonera Resource Centre when the University of Malta set up a community center in one of the socially deprived areas in Malta. Dr. Cutajar won the 2016 EPALE award for this project. Address corresspondence to: Dr. JosAnn Cutajar, Gender Studies Department, Room 114, Guze Cassar Pullicino Building, University of Malta, Msida MSD 2080, Malta; e-mail: josann.cutajar@um.edu.mt.
} 